\title{
Postmenopausal Low Level HCG and Management: A Case Report
}

\author{
Postmenopozal Düşük Seviye HCG ve Yönetimi: Olgu Sunumu \\ Aşkın Evren Güler ${ }^{1}$, Hüseyin Pehlivan ${ }^{2}$, Ahmet Ozek ${ }^{1}$, Ali Kolusarı ${ }^{3, *}$ \\ ${ }^{1}$ Private Koru Ankara Hospital, Clinics of Gynocology and Obstetrics, Ankara, Turkey \\ ${ }^{2}$ Private Koru Sincan Hospital, Clinics of Gynocology and Obstetrics, Ankara, Turkey \\ ${ }^{3} Y \ddot{u}$ rüncü Yil University, Department of Gynocology and Obstetrics, Van, Turkey
}

\begin{abstract}
In our case report 51-year-old, 1-year menopausal status, hCG positive, patient is discussed. Persistent low-level hCG secretion may be seen in such cases as: early pregnancy, gestational trophoblastic disease session, false positive hCG, pituitary hCG, non-gestational malignancies. When the conditions causing the elevated hCG are analyzed, it should not be forgotten that persistent low level hCG is experienced not only in pathological situations but also in physiological conditions. For this reason, it is important to avoid unnecessary invasive procedures and medical practices involving the use of chemotherapeutics to make accurate differential diagnosis.
\end{abstract}

Key Words: persistent low level hCG, pituitary hCG, postmenopausal

\section{Introduction}

Human Chorionic Gonadotropin (hCG) is a peptide hormone secreted by trophoblasts. The current hCG detection methods show almost $100 \%$ specificity and sensitivity. Pregnancy and gestational trophoblastic diseases (GTD) are the most common causes of the presence of elevated hCG level in blood or urine (1). In our clinical practice, persistent low level hCG may be observed in the following cases: early pregnancy (though rarely), active gestational trophoblastic diseases, false positive hCG, non-gestational malignancies and pituitary-dependent secretion of hCG.

Dependence of detected hCG levels on a clinically pathological or physiological process bears an utmost importance. While a healthy pregnancy in the early period may be described as a part of the pituitarydependent physiological hCG secretion, pathological hCG secretion may be mentioned during pathological cases of unhealthy pregnancy such as active

\section{ÖZET}

Olgu sunumuzda 1 ylllık menapozal statüde hCG pozitifliği tespit edilen 51 yaşındaki vaka tartışılmıştır. Düşük persiste hCG salınımı; erken gebelik dönemi, aktif gestasyonel trofoblastik hastalık, yanlış hCG pozitifliği, nongestasyonel maligniteler ve hipofizer kaynaklı hCG salınımı gibi durumlarda karşımıza çıkabilmektedir. hCG yüksekliğine neden olan durumlar incelendiğinde postmenopozal dönemdeki düşük seviye persiste hCG tespitinin her zaman patolojik durumlarla birlikte olmadığı, fizyolojik durumlarla da birlikte olabileceği unutulmamalıdır. Bu nedenle ayrıcı tanının net yapılarak, gereksiz invaziv işlem, kemoterapötik kullanımına varan tıbbi uygulamalardan kaçınılması önem arz etmektedir.

Anahtar Kelimeler: Düşük persiste hCG, hipofizer hCG, postmenapoz

gestational trophoblastic disease, non-gestational malignancies, ectopic pregnancy (2).

In the case report, the management of a postmenopausal patient with persistent low level within physiological limits has been discussed.

\section{Case Report}

The 51 year-old patient referred to our clinic due to positive serum hCG and one year menopausal status, is gravida 3, para 2, and has a history of 2 spontaneous vaginal deliveries and 1 early abortion. The patient has no medical history of surgery and internal diseases. The laboratory assessment indicates 3 hCG values of $45,29,40 \mathrm{mUI} / \mathrm{ml}$ assessed at 48 hour intervals for FSH:180 uu/ml, PRL: $28 \mathrm{uu} / \mathrm{ml}$, and TSH: $5,12 \mathrm{iu} / \mathrm{ml}$, respectively. hCG positive was detected in urine as the material obtained by our laboratory from urinary sediment was assessed by the serum hCG measurement technique. During vaginal sonography, the adnexal area was observed in normal

*Sorumlu Yazar: Ali Kolusari, MD, Yuzuncu Yil University, Faculty of Medicine Department of Obstetrics and Gynaecology, 65200 Van, Turkey, Tel: 0 (432) 21504 70, Fax: 0 (432) 21675 19, E-mail: dralikolusari@yahoo.com, dralikolusari@yyu.edu.tr 
condition and myometrium was homogenous; while the endometrial wall thickness was $7 \mathrm{~mm}$. Office hysteroscopy was planned for endometrial sampling in order to exclude the GTD and cavity and both tubal ostia were detected normal. Endometrial biopsy was performed by probe curettage. Biopsy material was reported as inactive endometrium. No mass or cases suggesting gestational trophoblastic diseases was seen in thoracoabdominopelvic contrast tomography and direct lung radiography. The current case was assessed as physiological elevated hCG. For a duration of 3 weeks, patients were given $50 \mathrm{mcg}$ of estrogen daily; and 2 hCG levels were measured with an interval of 48 hours. These levels have been detected as 12, $8 \mathrm{mUI} / \mathrm{ml}$, respectively. These results have clarified the presumed pituitary-dependent case.

\section{Discussion}

Persistent low levels of hCG with positive results correspond to the absence of gestational tropohoblastic activities under $1000 \mathrm{mIU} / \mathrm{ml}$ with a minimum measurement of 2 times in a 3 -month period. Positive persistent low level hCG represents the absence of gestational trophoblastic activity under $1000 \mathrm{mIU} / \mathrm{ml}$ by a minimum measure of 2 times in a 3 -month period by means of imaging methods. Low levels of hCG cause (intrauterine or ectopic pregnancy) during early pregnancy; (complete/partial moles, invasive moles, choriocarcinoma, placental site trophoblastic tumors) at active gestational trophobolastic diseases; phantom hCG (false positive hCG), non-gestational malignancies and physiological artifacts (pituitary hCG and midcycle luteinizing hormone (LH) secondary peak in women during the reproductive period). Such clinical results may occur both individually and concurrently as phantom hCG or pituitary hCG and gestational tropohoblastic dieases (2).

Investigating the causes of low level hCG, 2 main methods are suggested for the detection of false positive hCG (phantom hCG). The easiest and mostly preferred approach is the assessment of serum and urine in respect of hCG. Detection of hCG in the urine may lead to the exclusion of probability of phantom hCG. Another method is researching the serum hCG levels by 2 separate laboratories that employ diverse assessment techniques (3).

Apart from the coexistence of high hCG levels and cases of active gestational trophoblastic diseases, occurrence of low hCG levels in quiescent gestational trophoblastic diseases arises from inactive and non-invasive trophoblastic cells (4). This is actually a frequent case after the complete hydatiform moles. This case may also be observed following the choriocarcinoma, invasive mole and partial mole treatments. A study conducted by Cole et al. (2) has shown that hCG level was measured maximum 212 $\mathrm{mUl} / \mathrm{ml}$ with a minimum measurement of 2 times in a 3-month period. This level has regressively reached negative hCG levels in several cases. Spontaneous cases are available with positive hCG levels up to maximum 2 years (5). Hence, the treatment of elevated hCG levels in quiescent gestational trophoblastic diseases seems unnecessary. Nevertheless, patients examined during the reproductive period should be protected against pregnancy by means of methods including estrogen and progesterone; and pregnancy should be avoided by maintaining the 6 month negative hCG levels.

It should not be that neglected, the presence of intrauterine mass and low serum hCG level may cause placental site trophoblastic tumor (PSTT). This may also occur following the term pregnancy or a pregnancy case that occurred several years ago. A study by Cole et al. (4) found the median hCG level as $30 \mathrm{mUI} / \mathrm{ml}(1-231 \mathrm{mUI} / \mathrm{ml})$. A clear distinction should be made with the quiescent gestational trophoblastic diseases, having clinical and laboratory similarities. The $\beta$-subunit hCG is seen in PSTT and this is over $61 \%$ of the total hCG (5).

$\beta$-hCG coding gene sequences may be seen in nongestational malignancies. Activation of these genes may cause the release of low level hyperglucose free $\beta$-hCG (hCG-H). This enables the use of hCG-H as a tumor marker for the follow-up of prognosis (6).

Pituitary hCG may be detected at low levels in natural pituitary hCG and premenopausal and postmenopausal patient groups. In some studies, the highest detected value was 32 in $\mathrm{mUI} / \mathrm{ml}$ (7-9). Inhibition of GnRH and hCG release in cases treated with $50 \mathrm{mcg}$ estrogen preparation for 3 weeks following the analysis of other sources of hCG, clarifies that hCG is pituitary-dependent (9). LH serum levels increases in ovulation and menopausal status; and this induces the activation of hCG betasubunit gene nested with LH beta-subunit gene, which eventually causes the increase of serum hCG levels (10).

We conclude that the detection of the low level persistent hCG is not always associated with pathological cases, but, excluding malignancy or potential sources of hCG, it may be a physiological case caused by the secretion of pituitary hCG. Therefore, it is necessary to make an accurate differential diagnosis and avoid any medical practices involving unnecessary invasive procedures and use of chemotherapeutics. 


\section{References}

1. Niemann I, Vejerslev LO, Frøding L, Blaakær J, Maroun LL, Hansen ES, et al. Gestational trophoblastic diseases-clinical guidelines for diagnosis, treatment, follow-up, and counselling. Dan Med J 2015; 62(11): A5082.

2. Cole LA, Khanlian SA. Inappropriate management of women with persistent low hCG results. J Repro Med 2004; 49(6): 423-432

3. Cole LA, Dai D, Butler SA, Leslie KK, Kohorn El. Gestational trophoblastic diseases: 1. Pathophysiology of hyperglycosylated hCG. Gynecol Oncol 2006; 102(2): 145-150.

4. Cole LA, Ladner DG, Byrn FW. The normal variabilities of the menstrual cycle. Fertil Steril 2009; 91(2): 522-527.

5. Narayan P, Gray J, Puett D. Yoked complexes of human choriogonadotropin and the lutropin receptor: evidence that monomeric individual subunits are inactive. Mol Endocrinol 2002; 16(12): 2733-2745.

6. Pillai RN, Konje JC, Tincello DG, Potdar N. Role of serum biomarkers in the prediction of outcome in women with threatened miscarriage: a systematic review and diagnostic accuracy meta-analysis. Hum Reprod Update 2016; 22(2): 228-239.

7. Cole LA. Use of hCG tests for evaluating trophoblastic diseases: Choosing an appropriate hCG assay, false detection of hCG, unexplained elevated hCG, and quiescent trophoblastic disease. In: Gestational Trophoblastic Disease, 2nd, Hancock BW, Newland ES, Berkowitz RS, Cole LA (Eds), Chapman and Hall, London 2002. p.130.

8. Hancock BW, Tidy JA. Clinical management of persistent low-level hCG elevation. Trophobl Dis Upd 2004; 4: 5-6.

9. Kohorn EI. Persistent low-level "real" human chorionic gonadotropin: a clinical challenge and a therapeutic dilemma. Gynecol Oncol 2002; 85(2): 315320.

10. Narayan P. Genetic Models for the Study of Luteinizing Hormone Receptor Function. Front Endocrinol (Lausanne) 2015; 6: 152. 